\title{
PENGARUH KUALITAS SUMBER DAYA MANUSIA TERHADAP KINERJA PEGAWAI BADAN PENDIDIKAN DAN PELATIHAN PROVINSI KALIMANTAN TENGAH
}

\author{
Influence of human resources on the performance of Education service and training \\ of central Kalimantan province
}

\section{Masrukin* \\ Awina Theresia}

Universitas Muhammadiyah

Palangkaraya, Palangka Raya, Central

Kalimantan, Indonesia

email:

masrukin@umpalangkaraya.ac.id

\begin{abstract}
Abstrak
Penelitian ini bertujuan untuk mengatahui seberapa besar pengaruh kualitas sumber daya manusia terhadap kinerja pegawainya pada badan diklat provinsi Kalimantan Tengah. Metode yang digunakan dalam penelitian ini dengan teknik pengambilan sampel total sebanyak 25 orang yang terdiri dari, variable bebas $X$ (kualitas sumber daya manusia) dan variabel terikat $Y$ (kinerja). Data dikumpulkan melalui kuesioner dan dukung oleh studi perpustakaan. Teknik analisa data menggunakan Skala Likert.

Kulitas Sumber Daya Manusia berpengaruh Nyata Positif terhadap Kinerja Pegawai Badan Diklat Provinsi Kalimantan Tengah. Dengan kualitas sumber daya manusia yang terus ditingkatkan, baik dari segi pengetahuan maupun keterampilan yang disesuaikan dengan kebutuhan organisasi, maka pelaksanaan tugas dan fungsi tiap pegawai tesebut dapat dilakukan dengan optimal dan akan mendapatkan kinerja yang sesuai dengan yang direncanakan. Hal ini berdasarkan pengujian hipotesisi yang telah dilakukan. Persamaan regresi linier sederhana $y=4,435+27,97 x$. Dimana, apabila Pengaruh Kualitas Sumber Daya Manusia terhadap Kinerja di Badan Diklat Provinsi Kalimantan Tengah dinyatakan nol (0) maka Kinerja Badan Diklat sebesar 27,97.

Implikasi yang dapat direkomendasikan dalam penelitian ini sebagai berikut: (I) perlu diadakan diklat bagi para pegawai sebagai studi banding, (2) perlu pantaan dalam struktur organisasi agar penempatan pegwai sesuai dengan kehaliannya, (3) perlu menyelaraskan visi dan misi, pendekatan, strategi, dan kegiatan operasional agar tercipta kerjasama tim yang dapat memperkuat institusi itu sendiri.
\end{abstract}

Kata Kunci:

Kualitas

Sumber Daya Manusia

Kinerja

Keywords:

Quality

Human Resources

Performance

\section{Accepted}

June 2015

Published

Oktober 2015

\begin{abstract}
This research aims to understand how much influence the quality of human resources on its employees ' performance in the central Kalimantan Province training agency. The method used in this study with a total sampling technique of 25 people consisting of a free variable $X$ (human resource quality) and $Y$-bound variable (performance). Data is collected through questionnaires and supported by library studies. Data analysis techniques using a Likert scale.

Human resources ' Kulitas have significant positive impact on the performance of agency officers in central Kalimantan province. With the quality of human resources that are continuously improved, both in terms of knowledge and skills tailored to the needs of the Organization, the implementation of tasks and functions of each officer can be done optimally and will be Performance as planned. This is based on hypothesized testing that has been done. Simple linear regression equation $y=4,435$ $+27,97 x$. Where, when the effect of human resources quality on performance in the central Kalimantan Province training Agency was declared zero (0) the performance of the training body amounted to 27.97 .

The implications that can be recommended in this study are as follows: (I) need to be held for employees as a comparative study, (2) need to be reflected in the organizational structure to allow the placement of the Employees in accordance with their own, (3) need to harmonizes vision and mission, approaches, strategies, and operational activities to create teamwork that can strengthen the institution itself.
\end{abstract}

\section{PENDAHULUAN}

Pengembangan sumber data manusia merupakan suatu condition sine qua non, atau sesuatu yang tidak dapat dihindarkan yang harus terus dilakukan, dengan kata lin hal ini merupakan keharusan baik untuk menghadapi tuntutan tugas sekarang maupun untuk menjawab 
tantangan masa depan, karena bagaimanpun canggihnya sarana dan prasarana organisasi tanpa ditunjang oleh sumber daya manusia yang berkualitas itu tidak dapat maju dan berkembang. Sehubungan dengan peran manusia yang sangat penting dan strategis dalam organisasi termasuk pemerintah daerah sangat perlu dalam pengembangan sumber daya apartur, karena sumber daya apartur merupakan faktor produksi langsung dan terpenting dalam organisasi pemerintah daerah.

Upaya pengembangan dapat dilakukan melalui organisasi itu sendiri maupun diluar organisasi, seperti pendidikan dan pelatihan. Pentingnya kualitas sumber daya manusia tersebut karena peranannya sebagai motor penggerak yang dapat mempengaruhi kemampuan dan keberhasilan pencapaian kinerja yang menjai tujuan organisasi secara efektif dan efisien.

Kemampuan kerja berhubungan dengan pengetahuan, keterampilan, bakat, minat, dan pengalaman yang dibutuhkan seseorang agar dapat menyelesaikan tugastugas yang harus dilaksanakan sesuai dengan pekerjaan atau jabatan yang didudukinya. Sedangkan kemauan kerja merupakan perwujudan dari tinggi rendahnya motivasi, bersumber dari dorongan berbentuk kebutuhan dan keinginan tertentu yang menyebabkan seseorang melakukan tingkah laku tertentu pula. Kinerja yang rendah, menurunnya produktivitas dan mutu, serta kompleksitas masalah pembangunan yang semakin meningkat.

Selain program pendidikan dan pelatihan, motivasi kerja sebagai aspek psikologis individu pegawai merupakan faktor lain yang dapat meningkatkan kinerja pegawai. Karena lembaga bukan saja mengharapkan pegawai yang mampu, cakap, dan terampil, tetapi yang penting mereka mu bekerja dengan giat dan mempunyai keinginan untuk mencapai hasil yang maksimal, sebab kemampuan, kecakapan, dan keterampilan tidak ada artinya jika mereka tidak mau bekerja keras.
Uraian tersebut menjelaskan betapa pentingnya peranan pegawai sebagai sumber daya manusia dalam upaya mendukung keberhasilan organisasi. Namun masalah yang makin mendasar adalah masih lemahnya kualitas sumberdaya manusia yang dimiliki apartur dalam menghadapi perubahan dan perkembangan teknologi yang semakin pesat sehingga mempengaruhi kinerja organisasi itu sendiri.

Demikian halnya dengan Badan Pendidikan dan Pelatihan Provinsi Kalimantan Tengah, sebagai organisasi yang merupakan bagian dari pelaksana pembangunan dan pelaksana administrasi pada Pemerintah Provinsi Kalimantan Tengah, Badan Diklat dituntut untuk meningkatkan kemampuan aparturnya dalam menunjang keberhasilan pembangunan di wilayahnya.

Berdasarkan hasil observasi terhadap pegawai di lingkungan Kantor Badan Pendidikan dan Pelatihan, memiliki hambatan-hambatan dalam penyelenggaraan organisasi, yang tidak lain disebabkan oleh pegawai yang belum melaksanakan tugasnya secara optimal.

Berdasarkan pengamatan pendahuluan peneliti, pengembangan kualitas sumber data manusia di kantor Badan Pendidikan dan Pelatihan Provinsi Kalimantan tengah masih belum maksimal, baik yang bersidat formal maupun yang bersifat non-formal, serta belum sepenuhnya ada upaya untuk membangkitkan motivasi kerja pegawai untuk meningkatkan kinerja. Pengembangan kualitas sumber daya manusia tersebut diantaranya dengan mengikutsertakan para pegawai dalam diklat-diklat maupun studi banding agar membuka wawasan pegawai itu sendiri.

\section{Kualitas Sumber Daya Manusia}

Kata kualitas memiliki banyak definisi yang berbeda dan bervariasi, kualitas biasanya menggambarkan karaktersik langsung dari suatu produk seperti: tampilan luar, keandalan, mudah dalam penggunaan, estetika, dan sebagainya. 
Menurut Vincent Gasperzs (1997:5), kualitas diartikan sebagai segala sesuatu yang menentukan kepuasan pelanggan dan upaya perubahan ke arah perbaikan terus menerus, dikenal dengan istilah $\mathrm{Q}=$ Match (quality = Meets Agreed Terms and Change)

Philip B. Crosby (Nasution, 2003: 3) menyatakan bahwa kualitas adalah memenuhi atau sama dengan persyaratan (conformance of requirement). Meleset sedikit saja dari persyaratan, maka suatu produk atau jasa dikatakan tidak berkualitas. Peryaratan itu sendiri dapat berubah sesuai dengan keinginan pelanggan, kebutuhan organisasi, pemasok dan sumber pemerintahan, teknologi, serta pasar atau pesaing.

Definisi kualitas juga dikemukakan oleh Gevin dan Davis (Nasution, 2005: 3) menyatakan bahwa kualitas adalah suatu kondisi yang dinamis yang berhubungan dengan produk, manusia atau tenaga kerja, proses, tugas, serta lingkungan yang memenuhi atau melebihi harapan pelanggan atau masyarakat.

Indikator kualitas kerja mengacu pada kualitas sumber daya manusia (Matutina, 200I: 205) yaitu:

1. Pengetahuan (Knowledge), yaitu kemampuan yang dimiliki karyawan lebih berorientasi kepada intelejensi dan daya pikir serta penguasaan ilmu yang luas yang dimiliki karyawan.

2. Keterampilan (Skill), kemampuan dan penguasaan teknis operasional dibidang tertentu yang dimiliki karyawan.

3. Kemampuan (Abilities) yaitu kemampuan yang terbentuk dari sejumlah kompetensi yang dimiliki oleh seorang karyawan yang mencakup loyalitas, kedisiplinan, kerjasama, dan tanggung jawab.

Kualitas sumber daya manusia menurut Ruky (2003: 57) adalah tingkat pengetahuan, kemampuan, dan kemauan yang dapat ditunjukan oleh sumber daya manusia. Kemampuan pegawai sebagai sumber daya manusia dalam suatu organisasi sangat penting arti dan keberdaannya untuk peningkatan produktivitas kerja dilingkungan organisasi.
Menurut Koeswara

(2001:266-267)

menyatakan bahwa konteks kualitas sumbr daya manasia apartur di era otonomi daerah adalah kemampuan profesional dan keterampilan teknis para pegawai termasuk unsur staff dan pelaksanaannya di lingkungan pemerintah daerah. $\mathrm{Hal}$ ini sangat diperlukan agar manajemen pemerintah dalam otonomi daerah dapat berlangsung secara efektif dan efisien. Yang diperlukan tidak hanya jumlah yang cukup, tetapi juga kualitas para pegawai yang harus diukur dengan latar belakang pendidikan, keterampilan, pengalaman kerja, jenjang kepangkatan, dan status pegawai.

\section{Kinerja}

Pengertian kinerja menurut lembaga LAN dalam Supriyatna (2000:132) adalah “Prestasi kerja, pelaksanaan kerja, pencapaian kerja atau hasil kerja atau penampilan kerja (yang diterjemahkan dari Performance). Sedangkan fieldman dalam Supriyatna (2000:132) mengemukakan bahwa, "Prinsip dasar manajemen adalah kinerja yang merupakan perpaduan antara motivasi yang ada pada diri seseorang dan kemampuannya dalam melaksanakan suatu pekerjaan”.

Selanjutnya Nawawi (2000:142) menyatakan bahwa kinerja dalam arti untuk perilaku dalam bekerja (Performance) yang positif, meurpakan gambaran konkrit kemampuan dalam mendayagunakan sumbersumber kualitas, yang berdampak pada keberhasilan mewujudkan, mempertahankan, dan mengembangkan eksistensi non-profit. Kinerja yang tinggi terlihat dari proses pelaksanaan pekerjaan yang berlangsung efektif dan efisien, yang terus menerus diperbaiki kualitasnya. Disamping itu juga dapat diketahui dari prestasi atau hasil kerja yang berkualitas, dan selalu sesuai dengan keinginan dan harapan masyarakat yang dilayani, sebagai bukti bahwa sumber-sumber kualitas digunakan secara efektif.

I. Faktor-faktor yang Mempengaruhi Kinerja

a. Efektifitas dan Efisiensi 
Bila suatu tujuan akhirnya bisa tercapai, kita bisa mengatakan bahwa kegiatan tersebut efektif.

b. Otoritas (wewenang)

Adalah sifat dari suatu komunikasi atau perintah dalam suatu organisasi formal yang dimiliki seorang anggota organisasi kepada anggota yang lain untuk melakukan suatu kegiatan kerja sesuai dengan kontribusinya. Perintah tersebut mengatakan apa yang boleh dilakukan dan yang tidak boleh dalam organisasi tersebut.

c. Disiplin

Adalah taat kepada hukum dan peraturan yang berlaku. Disiplin karyawan adalah kegiatan karyawan yang bersangkutan dalam menghormati perjanjian kerja dengan organisasi dimana dia bekerja.

d. Inisiatif

Berkaitan dengan daya pikir dan kreatifitas dalam membentuk ide untuk merencanakan sesuatu yang berkaitan dengan tujuan organisasi.

(Prawirosentono, 1999:27)

2. Karakteristik Kinerja Karyawan

Karakterisitik orang yang mempunyai kinerja tinggi, pendapat dari (Mangkunegara,2002:68) adalah sebagai berikut:

a. Memiliki tanggung jawab pribadi yang tinggi

b. Berani mengambil dan menanggung resiko yang dihadapi

c. Memiliki tujuan yang realistis

d. Memiliki rencana kerja yang menyeluruh dan berjuang untuk merealisasi tujuannya

e. Memanfaatkan umpanbalik (Feedback) yang konkrit dalam seluruh kegiatan kerja yang dilakukannya

f. Mencari kesempatan untuk merealisasikan rencana yang telah diprogramkan

3. Indikator Kinerja Karyawan

$$
\text { Indikator untuk mengukur kinerja }
$$

karyawan secara individu ada 5 indikator (Robbins, 2006:260), yaitu: a. Kualitas. Kualitas kerja diukur dari persepsi karyawan terhadap kualitas pekerjaan yang dihasilkan serta kesempurnaan tugas terhadap keterampilan dan kemampuan karyawan

b. Kuantitas. Merupakan jumlah yang dihasilkan. Dinyatakan dalam istilah seperti jumlah unit, jumlah siklus aktivitas yang diselesaikan

c. Ketepatan Waktu. Merupakan tingkat aktivitas diselesaikan pada awal waktu yang dinyatakan, dilihat dari sudut koordinasi dengan hasil output, serta memaksimalkan waktu yang tersedia dengan aktivitas lain.

d. Efektivitas. Merupakan tingkat penggunaan sumber daya organisasi (tenaga, uang, teknologi, bahan baku) dimaksimalkan dengan maksud menaikan hasil dari setiap unit dalam penggunaan sumber daya.

e. Kemandirian. Merupakan tingkat seorang karyawan yang nantinya akan dapat menjalankan fungsi kerjanya.

4. Tugas Badan Kepegawaian Pendidikan dan Pelatihan

Badan kepegawaaian mempunyai tugas di bidang Pendidikan dan Pelatihan. Untuk melaksanakan tugas pokok sebagaimana dimaksud Badan Pendidikan dan Pelatihan menyelenggarakan fungsi:

a. Perumusan bahan pembinaan dan kebijakan teknis di bidang pendidikan dan pelatihan

b. Penyiapan bahan pembinaan pendidikan dan pelatihan, dan menghimpun peraturan perundangundangan di bidang pendidikan dan pelatihan

c. Penyiapan penyusunan peraturan perundangundangan daerah di bidang pendidikan dan pelatihan, sesuai dengan norma, standar dan prosedur yang ditetapkan pemerintah

d. Penyiapan dan penyusunan perogram peningkatan kualitas PNSD antara lain melalui pendidikan dan pelatihan

e. Pelaksanaan koordinasi kebijakan di bidang pendidikan dan pelatahian struktural, kader, teknis 
administrasi/subtantif, fungsional, kemasyarakatan, dan teknis sektoral

f. Palaksanaan koordinasi dan bimbingan kelompok jabatan fungsional'

g. Pembinaan, pelayanan, pengawasan, pengendalian, monitoring, evaluasi, dan pelaporan penyelenggaraan pendidikan dan pelatihan

h. Penyelenggaraan urusan kesekretariatan Badan Diklat

Untuk melaksanakan fungsi sebagaimana dimaksud, Badan Pendidikan dan Pelatihan mempunyai kewenangan sebagai berikut:

a. Melaksanakan orientasi tugas dan prajabatan

b. Penetapan kebutuhan diklat PNS Daerah Provinsi dan penyelenggaraan diklat

c. Pemutakhiran data alumni peserta pendidikan dan pelatihan, pengawasan, dan pengendalaian atas pelaksanaan peraturan perundang-undangan di bidang pendidikan dan pelatihan skala provinsi dan di lingkungan kabupaten/kota

d. Penyelenggaraan pembinaan dan pengawasan manajemen Pendidikan dan Pelatihan PNS di lingkungan provinsi

e. Penyusunan program pengelolaan pelaksanaan pendidikan dan pelatihan, pelaksanaan pembelajaran dan pelatihan, seminar, rapat koordinasi serta bimbingan teknis pendidikan dan pelatihan

f. Penyelenggaraan urusan kesekretariatan Badan Pendidikan dan Pelatihan.

Menurut Siagian (dalam Hessel Nogi, 1998:178) bahwa pendidikan adalah keseluruhan proses, teknik, dan metode belajara mengajar dalam rangka mengalihkan suatu pengetahuan dari seseorang kepada orang lain sesuai dengan standar yang telah ditetapkan sebelumnya.

Nawawi (2000:358) mengatakan bahwa pelatihan merupakan penigkatan pelatihan kerja yang dibutuhkan untuk melaksanakan pekerjaan seseorang dan dapat digunakan untuk pengembangan pegawai dalam menghadapi peningkatan tanggung jawab di masa mendatang bersama dengan pengingkatan kepangkatannya, serta dilakukan untuk pegawai yang lama dan yang baru.

\section{METODOLOGI}

Dalam penelitian ini penulis menggunakan Pendekatan Kuantitatif. Sampel penelitian ini adalah seluruh Pegawai Negeri Sipil di lingkungan Badan Pendidikan dan pelatihan Provinsi Kalimantan Tengah dengan jumlah 52 orang dan pegawai peserta diklat dari instansi lain 48 orang.

Penelitian Kuantitatif adalah metode penelitian yang berlandaskan pada filsafat positivisme. Digunakan untuk meneliti populasi atau sampel tertentu, teknik pengambilan sampel pada umumnya random atau acak, pengumpulan data menggunakan instrumen penelitian, analisa data bersifat kuantitatif atau statistik dengan tujuan untuk menguji hipotesis yang telah ditetapkan. Penelitian ini dilakukan selama 3 (tiga) bulan, yaitu sejak tanggal 25 Januari 2015 sampai dengan 25 Maret 2015. Penelitian dilaksanakan di Kantor Badan Pendidikan dan Pelatihan Provinsi Kalimantan Tengah.

\section{HASIL DAN PEMBAHASAN}

Berdasarkan hasil penelitian Kualitas Sumber Daya Manusia di Badan Pendidikan dan Pelatihan Provisni Kalimantan Tengah dilihat dari Pengetahuan, Keterampilan, dan Kemampuan sudah baik. Akantetapi, pada dimensi keterampilan dan kemampuan masih ada kekurangan, untuk dimensi keterampilan masih ada kekurangan karena:

a. Dalam hal penempatan pegawai pada bidang masing-masing masih ada yang tidak sesuai dengan keahlian ataupun kemampuan yang dimiliki pegawai yang bersangkutan.

b. Secara teknis masih ada beberapa pegawai yang belum menguasai pekerjaan yang seharusnya menjadi tanggung jawab pegawai yang 
bersangkutan, sehingga hal ini perlu ditingkatkan lagi.

Sedangkan untuk dimensi Kemampuan pegawai pada Badan Diklat masih memiliki kekurangan karena:

a. Kemampuan unruk berkoordiansi ataupun bekerjasama antar beberapa pegawai yang satu dengan pegawi lainnya masih dinilai kurang oleh karena itu hal ini perlu diperhatikan dan ditingkatkan agar menghasilkan kerjasama yang solid sehingga hasil kerja pun sesuai dengan yang diharapkan.

b. Dalam hal Motivasi Kerja Pegawai sudah baik, namun berdasarakan penelitian di lapangan, masih ada beberapa keluhan bahwa motivasi kerja hanya didasarkan pada materi yang akan diperoleh, seihngga hasil kerja yang diperoleh belum maksimal. Oleh karena itu harus dicari jalan keluar untuk memotivasi para pegawai tersebut, misalnya dengan Reward untuk pegawai yang rajin dan Punishment untuk pegawai yang malas.

Kinerja Pegawai di Badan Diklat Provinsi Kalimantan Tengah

Berdasarkan hasil penelitian kinerja pegawai di Badan Diklat Provinsi Kalimantan Tengah, dilihat dari dimensi kualitas dengan indikator kemampuan mengahadapi masalah yang timbul dalam pekerjaan dan kualitas kerja pegawai dalam menyelesaikan pekerjaan sudah baik, namun masing masing indikator tersebut masih perlu ditingkatkan karena masih ada keluhan dari beberapa responden. Sementara untuk dimensi kuantitas dalam hal efisiensi pegawai dalam mempergunakan wkatu bekerja, sudah baik, tetapi pekerjaan yang dihasilkan masih perlu ditingkatkan agar sesuai dengan harapan dan sasaran kerja.

Pada dimensi efektifitas, dalam hal ketersediaan dan pemanfaatan sarana oleh pegawai masih ada kekurangan. Ketersediaan sarana mungkin berkaitan dengan dana Badan Diklat itu sendiri, sedangkan pemanfaatan saranamasih ada beberapa pegawai yang kurang memahami atau belum dapat mempergunakannya. Komitmen pegawai terhadap pekerjaan pada dimensi kemandirian sudah cukup baik namun belum optimal. Oleh karena itu perlu mendapatkan perhatian agar lebih ditingkatkan lagi supaya pekerjaan yang dilakukan dapat terlaksana sesuai dengan yang diharapkan, begitu pula dengan tanggung jawab terhadap pekerjaan dan instansi tempatnya bekerja.

Pengaruh Kualitas Sumber Daya Manusia Terhadap Kinerja Pegawai badan Diklat Provinsi Kalimantan Tengah. Berdasarkan hasil penelitian bahwa ada pengaruh yang positif antara kualitas SDM terhadap Kinerja Pegawai Badan Diklat Provinsi Kalimantan Tengah, hal ini disebabkan karena:

a. Dengan kualitas sumber daya manusia yang terus ditingkatkan baik dari segi pengetahuan maupun keterampilan yang disesuaikan dengan kebutuhan organisasi, maka pelaksanaan tugas dan fungsi dari tiap pegawai tersebut dapat dilakukan dengan optimal dan akan mendapatkan hasil yang sesuai dengan yang direncanakan

b. Untuk menghasilkan kinerja yang berkualitas, efektif, dan efisien, maka diperlukan kemampuan serta pengalaman yang memadai dari sumber daya manusia itu sendiri.

\section{KESIMPULAN}

Berdasarkan hasil penelitian, dan hasil analisis data yang peneliti lakukan di Kantor Badan Diklat Provinsi Kalimantan Tengah, dapat disimpulkan dengan hasil analisis menggunakan rumus regreis linier sederhana didapatkan persamaan regresi sebesar $y=7,84+32,75 x$. Dimana Kualitas Sumber Daya Manusia berpengaruh Nyata Positif terhadap Kinerja Badan Diklat Provinsi Kalimantan Tengah, yang terdiri dari:

I. Pengetahuan merupakan domain yang sangat penting, oleh karena itu Kualitas Pengetahuan 
berpengaruh signifikan dalam meningkatkan kinerja baik kualitas kerja maupun efektifitas pekerjan.

2. Keterampilan adalah kecakapan yang berhubungan dengan tugas yang dimiliki dan dipergunakan oleh seseorang pada waktu yang tepat. Maka kualitas sumber daya manusia pada dimensi Keterampilan berpengaruh signifikan terhadap kualitas kerja.

3. Kemampuan merupakan kapabilitas individu dalma melakukan pekerjaannya secara tepat dan bertanggung jawab, oleh sebab itu kualitas sumber daya manusia pada dimensi Kemampuan berpengaruh signifikan terhadap kinerja dalam Kemandirian dan Ketepatan Waktu menyelesaikan pekerjaan.

Maka peneliti memberikan saran yakni Kepala Badan Diklat Provinsi Kalimantan Tengah dalam menempatkan pegawai sesuai kompetensinya baik untuk jabatan teknis, struktural, maupun jabatan fungsional. Kemudian, Diharapkan kepada Kepala Badan Diklat Provinsi Kalimantan Tengah dapat meningkatkan diklat teknis maupun diklat fungsional terhadap seluruh pegawai agar memiliki kemampuan dan pengetahuan yang memadai sehingga kinerja yang ingin dicapai dapat lebih optimal. Dan Diharapkan bagi pegawai Badan Diklat Provinsi Kalimantan Tengah perlu meningkatkan diri pada dimensi Pemanfaatan Waktu yaitu pemanfaatan dalam menggunakan waktu kerja maupun waktu luang oleh pegawai. Serta perlu meningkatkan diri pada dimensi Komitmen Kerja yaitu bagaimana komitmen pegawai terhadap pekerjaan masing-masing agar dapat diselesaikan sesuai yang direncanakan.

\section{REFERENSI}

Gaspersz, Vincent. 1997. Manajemen Kualitas, Penerapan Konsep-konsep Kualitas Dalam Manajemen Bisnis Total. Jakarta: PT Gramedia.

Hasibuan, 2007. Manajemen Sumber Daya Manusia. Jakarta: Bumi Aksara.

Koswara. 200I. Dinamika Informasi dalam Era Global. Jakarta: CV Rajawali.

Nasution, MN. 2005. Manajemen Mutu Terpadu. Jakarta: Ghalia Indonesia.

Nawawi, Hadari. 2000. Manajemen Stratejik Organisasi non Profit Bidang Pemerintahan (dengan ilustrasi Bidang Pendidikan). Yogyakarta: Gajah Mada Press.

Robbins, Stephen P. 2006. Perilaku Organisasi, PT Indeks, Kelompok. Jakarta: PT Gramedia.

Rucky, Ahmad S. 2003. Sumber Daya Manusia Berkualitas (Mengubah Visi menjadi Realitas). Jakarta: PT Gramedia.

Siagian. 1998. Organisasi Kepemimpinan dan Perilaku Organsiasi. Jakarta: Bumi Aksara.

Sibarani, Mutiara. 2004. Manajemen Sumber Daya Manusia. Jakarta: Ghalia Indonesia.

Sugiono. 2007. Metode Penelitian Administrasi. Bandung: Alfabeta.

Supriyatna. 2000. Akuntabilitas Pemerintahan dalam Administrasi Publik. Bandung: CV Indra Prahasta 